\title{
Retrospective Analysis of Equine General Anesthesia Performed at Korea Racing Authority
}

\author{
Ahrham Kim***, Youngjin Yang**, Daeyoung Song**, Jinkap Kim**, Hagi Kim**, \\ Cheoljae Kwon**, Eugene Seo**, Hyohoon Jeong** and Inhyung Lee*1 \\ *Department of Veterinary Clinical Sciences, College of Veterinary Medicine, Seoul National University, Seoul 151-742, Korea \\ **Equine Hospital of Korea Racing Authority, Gwacheon 427-711, Korea
}

(Accepted: March 27, 2014)

\begin{abstract}
This study was conducted to analyze the results of inhalation anesthesia performed at the equine hospital of Korea Racing Authority (KRA) and to find out the influencing factors on mortality during and/or after inhalation anesthesia. Among 585 cases of anesthesia, orthopedic surgery (410) was performed the most frequently, followed by colic surgery (85) and upper airway surgery (45). Twenty out of 585 horses were either euthanized or died during and/or after anesthesia. Among those twenty horses, fourteen horses received colic surgery, three received orthopedic surgery, and three others received upper airway surgery. The major causes of mortality were rupture of intestine in colic surgery and airway obstruction during recovery in upper airway surgery. Myopathy, refracture, laminitis were the causes of mortality in orthopedic surgery. Consequently, the horses that received colic and upper airway surgeries showed significantly high mortality rate rather than horses that received orthopedic surgery $(p<0.01)$. According to the results, horses that received colic surgery showed the highest mortality rate from euthanasia due to poor and grave prognosis. To reduce the perioperative mortality of horses, it is recommended to perform perioperative intensive care for colic surgery and careful monitoring for upper airway surgery during recovery.
\end{abstract}

Key words : general, inhalation, anesthesia, mortality, horse.

\section{Introduction}

General inhalation anesthesia has been routinely performed in equine practice and considered as a fundamental step to treat horses with alimentary, upper airway and orthopedic diseases. The incidence of mortality and serious morbidity associated with clinical equine anesthesia are considerably higher than in other domestic species $(2,10)$.

Several studies have been published over years describing the perioperative mortality rates in equine patients. In the study of confidential enquiry of perioperative equine fatalities (CEPEF), the overall mortality rate within 7 days of anesthesia for non-colic cases was $0.8 \%$, while colic cases were nearly $8 \%$ (9). In another study, the mortality rate in 35,927 non-colic operations was $0.9 \%$, and in 5833 colic operations was $7.9 \%(8)$.

Anesthesia-related mortality in horses lies between $0.12 \%$ and $0.9 \%$ (1). The mortality rate for horses undergoing emergency procedures has been shown to be as high as $31.4 \%$ for all emergencies $(5,11)$. A retrospective analysis of anesthesiaassociated mortality reported overall death rate as $1.6 \%(15)$. The $32 \%$ of horses among those deaths had been humanly euthanized because of myopathies or fractures found during

${ }^{1}$ Corresponding author.

E-mail : inhyunglee@snu.ac.kr recovery (15). Although the mortality rate after anesthesia may be different depending on diseases and preoperative condition of horses, it is necessary to evaluate anesthetic results to reduce the mortality of patients during perioperative period.

Many surgeries requiring general anesthesia were performed over recent decades in KRA equine hospital. However, there are no overall evaluated data of general anesthesia records and retrospective study of perioperative equine fatalities. The objectives of the study were to analyze the results of inhalation anesthesia performed at the equine hospital of KRA, and determine risk factors associated with the mortality during and/or after inhalation anesthesia.

\section{Materials and Methods}

\section{Data collection}

A total of 585 horses anesthetized at the equine hospital of KRA in Gwacheon and Pusan from 2001 to 2013 were reviewed. The horses were either KRA racing horses or horses that required surgery under general anesthesia from outside of KRA. Anesthetic records were not included in the analysis if they missed more than five items in the record. As some records were excluded in each item, total numbers of analyzed records were different from the total number of the general inhalation anesthesia records.

Data from anesthetic records included date of anesthesia, 
breed, age, sex, body weight, anesthetic duration, surgical procedure type, inhalation agent concentration (vaporizer setting, inspiratory, and expiratory gas), heart rate (HR), systolic blood pressure (SBP), mean blood pressure (MBP), diastolic blood pressure (DBP), respiratory rate (RR) and post-anesthetic complications. Unusual events which occurred during or after anesthesia were noted in a comments column in the anesthetic record.

\section{Patient management}

Horses were fasted overnight prior to anesthesia except for those that received emergency surgery. About 2 hours before induction, blood sample was collected for hematological and biochemical analyses. Immediately before induction of anesthesia, horses were sedated with detomidine (Domosedan ${ }^{\circledR}$; Pfizer, USA, 20 40 $\mu \mathrm{g} / \mathrm{kg}$, IV). Ketamine with either diazepam (Diazepam $\mathrm{HCl}^{\circledR}$; Samjin, Korea, 0.02 0.11 mg/kg, IV) or guaifenesin $\left(\right.$ Giafen $^{\circledR}$; Bayer, Germany, 50 100 mg/kg, IV) were used for induction of anesthesia. Once horses became laterally recumbent, oro-tracheal intubation was performed. All horses were controlled by a circle rebreathing anesthetic system at $100 \%$ oxygen with intermittent positive pressure ventilation. Anesthesia was maintained with isoflurane (Ifrane ${ }^{\mathbb{R}}$; Hana, Korea) and a ventilation circuit. An indwelling catheter was installed at the facial and/or metatarsal artery depending on the position and surgery type, and connected to a calibrated pressure transducer (Transpac IV monitoring kit $^{\mathbb{R}}$; Hospira, Ireland) to monitor direct blood pressure (BP). If MBP was lower than $60 \mathrm{mmHg}$ during anesthesia, dobutamine $\mathrm{HCl}$ (Dobutrex ${ }^{\circledR}$; Hana, Korea) was administered to maintain MBP above $60 \mathrm{mmHg}$. During anesthesia, each horse was monitored every 10 minutes with an anesthetic multiparameter monitor (Solar $8000^{\circledR}$; JD Medical, USA).

After surgery, horses were moved to a recovery room and ventilated until they were able to initiate spontaneous breathing. The recovery dose of xylazine $\left(\right.$ Rompun $^{\circledR}$; Bayer, USA, $1.1 \mathrm{mg} / \mathrm{kg}, \mathrm{IV}$ ) was usually administered for smooth recovery. Nasal insufflation of pure oxygen at $10 \mathrm{~L} /$ minutes was given until they started to stand up by themselves. Horses were allowed to recover without assistance in a padded recovery stall.

\section{Statistical analyses}

Analysis was conducted by statistical software (Stata ${ }^{\circledR}$; Version 12, Stata Corp LP, College Station, USA). The mean \pm SD (range) were calculated from numerical data. Logistic regression analysis and chi square test were used to assess the relationship between perioperative factors and mortality. Statistical significance was attributed when $p$ value was under than 0.05 .

\section{Results}

The mean age of the 585 horses was $3.98 \pm 3.13$ years (range 1-22 years). Among 558 horses, 223 (40.0\%) were females,
Table 1. Mortality according to breed of horses

\begin{tabular}{ccccc}
\hline \hline \multirow{2}{*}{ Breed } & \multicolumn{2}{c}{ No. of Horses } & \multirow{2}{*}{ Total } & $\begin{array}{c}\chi^{2} \\
p\end{array}$ \\
\cline { 2 - 3 } & Alive & Dead & & $p$ \\
\hline TB & $460(97.0 \%)$ & $14(3.0 \%)$ & $474(100 \%)$ & \\
NTB & $93(93.9 \%)$ & $6(6.1 \%)$ & $99(100 \%)$ & 2.828 \\
F & $12(100 \%)$ & $0(0.0 \%)$ & $12(100 \%)$ & .243 \\
\cline { 1 - 3 } Total & $565(96.6 \%)$ & $20(3.4 \%)$ & $585(100 \%)$ & \\
\hline
\end{tabular}

F: foals, NTB: non-thoroughbred, TB: thoroughbred

Table 2. Mortality according to weight of horses

\begin{tabular}{ccccc}
\hline \hline \multirow{2}{*}{ Weight } & \multicolumn{2}{c}{ No. of Horses } & Total & $\begin{array}{c}\chi^{2} \\
p\end{array}$ \\
\cline { 2 - 3 } & Alive & Dead & & \\
\hline$\geq 500 \mathrm{~kg}$ & $429(97.5 \%)$ & $11(2.5 \%)$ & $440(100 \%)$ & \\
$<500 \mathrm{~kg}$ & $128(93.4 \%)$ & $9(6.6 \%)$ & $137(100 \%)$ & 5.170 \\
\cline { 2 - 4 } Total & $557(96.5 \%)$ & $20(3.5 \%)$ & $577(100 \%)$ & $.023^{*}$ \\
\hline${ }^{*} p<0.05$ & & & &
\end{tabular}

$236(42.3 \%)$ were sexually intact males, and 99 (17.7\%) were castrated males. Among 585 cases, 474 (81\%) cases were thoroughbred (TB), 99 (17\%) cases were non-thoroughbred (NTB) and $12(2 \%)$ cases were foals $(F)$. There was no significant correlation between breed and mortality (Table 1).

Among 577 cases, the mean body weight of horses was $472.6 \pm 50.4 \mathrm{~kg}$ (range $141-675 \mathrm{~kg}$ ). The weight of $440(76.2 \%)$ horses was less than $500 \mathrm{~kg}$, and the weight of $137(23.7 \%)$ horses was over $500 \mathrm{~kg}$. There was a significant correlation between weight and mortality (Table 2).

Among 464 horses, 405 (88.5\%) were positioned in dorsal recumbency (DR) during anesthesia, $43(10.6 \%)$ were in right lateral recumbency (RLR), and $20(4.9 \%)$ were in left lateral recumbency (LLR). There was no significant correlation between patient position and mortality.

Among 585 cases of anesthesia, orthopedic surgery (410) was the most frequently performed surgery and followed by colic surgery (85), castration (71), and upper airway surgery (45). Mortality rates among horses that underwent colic and upper airway surgery were significantly higher compared to the horses that underwent other types of surgery (Table 3 ).

The mean duration time from starting inhalation anesthesia to surgical incision was $25.7 \pm 9.8 \mathrm{~min}(\mathrm{n}=584$, range $10-80$ $\min )$. The mean anesthetic duration was $128.1 \pm 49.1 \mathrm{~min}(\mathrm{n}=$ 584, range 20-300 $\mathrm{min}$ ). The mean recovery period was $48.9 \pm$ $24.9 \mathrm{~min}(\mathrm{n}=35$, range $15-120 \mathrm{~min})$ since the surgery was ended.

The mean $\pm \mathrm{SD}$ of HR for horses during anesthesia was $36.1 \pm 7.3 \mathrm{beat} / \mathrm{min}(\mathrm{n}=554)$. The mean $\pm \mathrm{SD}$ of HR for horses at 30 minutes after starting inhalation anesthesia was $34.4 \pm 7.9$ beat $/ \min (n=439)$. It increased according to the surgery time (Fig 1).

The mean SBP, MBP and DBP were $98.6 \pm 18.2 \mathrm{mmHg}$ $(\mathrm{n}=553$, range $46-151 \mathrm{mmHg}), 71.7 \pm 17.7 \mathrm{mmHg}(\mathrm{n}=554$, 
Table 3. Mortality according to surgical procedures of horses

\begin{tabular}{|c|c|c|c|c|c|}
\hline \multirow{2}{*}{ Surgery type } & \multicolumn{2}{|c|}{ No. of Horses } & \multirow{2}{*}{ Total } & \multirow{2}{*}{ Frequency } & \multirow{2}{*}{$\begin{array}{l}\chi^{2} \\
p\end{array}$} \\
\hline & Alive & Dead & & & \\
\hline Castration & $11(91.7 \%)$ & $1(8.3 \%)$ & $12(100 \%)$ & $12(12.1 \%)$ & \\
\hline Colic & $72(84.7 \%)$ & $13(15.3)^{*}$ & $85(100 \%)$ & $85(14.5 \%)$ & \\
\hline Ortho (I) & $70(98.6 \%)$ & $1(1.4 \%)$ & $71(100 \%)$ & $71(12.1 \%)$ & \\
\hline Ortho (NI) & 337 (99.4\%) & $2(0.6 \%)$ & $339(100 \%)$ & $339(57.9 \%)$ & 48.871 \\
\hline Soft tissue & $17(100 \%)$ & $0(0.0 \%)$ & $17(100 \%)$ & $17(2.9 \%)$ & $.000^{*}$ \\
\hline Upper Airway & $42(93.3 \%)$ & $3(6.7 \%)^{*}$ & $45(100 \%)$ & $45(7.7 \%)$ & \\
\hline Others & $16(100 \%)$ & $0(0.0 \%)$ & $16(100 \%)$ & $16(2.7 \%)$ & \\
\hline Total & $565(96.6 \%)$ & $20(3.4 \%)$ & $585(100 \%)$ & $585(100 \%)$ & \\
\hline
\end{tabular}

Ortho (I): invasive orthopedic surgery, Ortho (NI): non-invasive orthopedic surgery, ${ }^{*} p<0.01$

range $32-138 \mathrm{mmHg})$, and $58.0 \pm 18.0 \mathrm{mmHg}(\mathrm{n}=552$, range 20-110 $\mathrm{mmHg}$ ) during anesthesia, respectively. BP was maintained within normal ranges through the surgery (Fig 2). The SBP, MBP, DBP decreased when the total anesthesia time exceeded 230 minutes because of the longer duration of anesthesia with a few patients. The SBP, MBP, DBP were $83.9 \pm$ $13.1 \mathrm{mmHg}(\mathrm{n}=12$, range $60-114 \mathrm{mmHg}), 58.1 \pm 13.2 \mathrm{mmHg}$ $(\mathrm{n}=11$, range $33-78 \mathrm{mmHg})$, and $44.5 \pm 14.8 \mathrm{mmHg}(\mathrm{n}=11$, range $17-68 \mathrm{mmHg}$ ) at 240 minutes after starting inhalation anesthesia.

Anesthetic agent concentration was recorded by vaporizer setting percentage (Fig 3). Anesthetic agent concentration decreased when the level of anesthesia reached the surgical

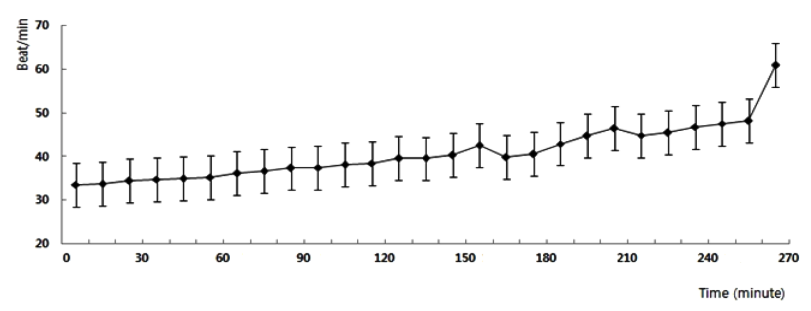

Fig 1. Changes in heart rate according to the anesthesia time. phase, which was evaluated by assessing palpebral reflex and corneal reflex. The mean vaporizer setting was $3.5 \pm 0.6 \%$ $(\mathrm{n}=583$, range $2-5 \%)$. The vaporizer setting at 30 minutes after starting inhalation anesthesia was $4.0 \pm 1.0 \%(\mathrm{n}=583$, range $2-5 \%$ ). The mean inspiratory and expiratory anesthetic gas concentration were $2.1 \pm 0.4 \%(n=34$, range $1.3-3.0 \%)$ and $1.6 \pm 0.3 \%(\mathrm{n}=34$, range $1.0-2.2 \%)$ during maintenance of anesthesia, respectively.

Among 585 of the anesthetic cases, 20 horses were euthanized or died during and/or after anesthesia. Among 20 horses, 14 received colic surgery, 3 received orthopedic surgery, and 3 received upper airway surgery. Horses that received colic surgery and airway surgery showed significantly higher mor-

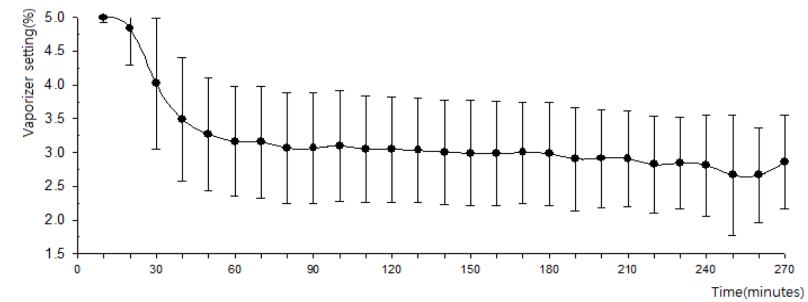

Fig 3. Changes in vaporizer setting percentage during anesthesia.

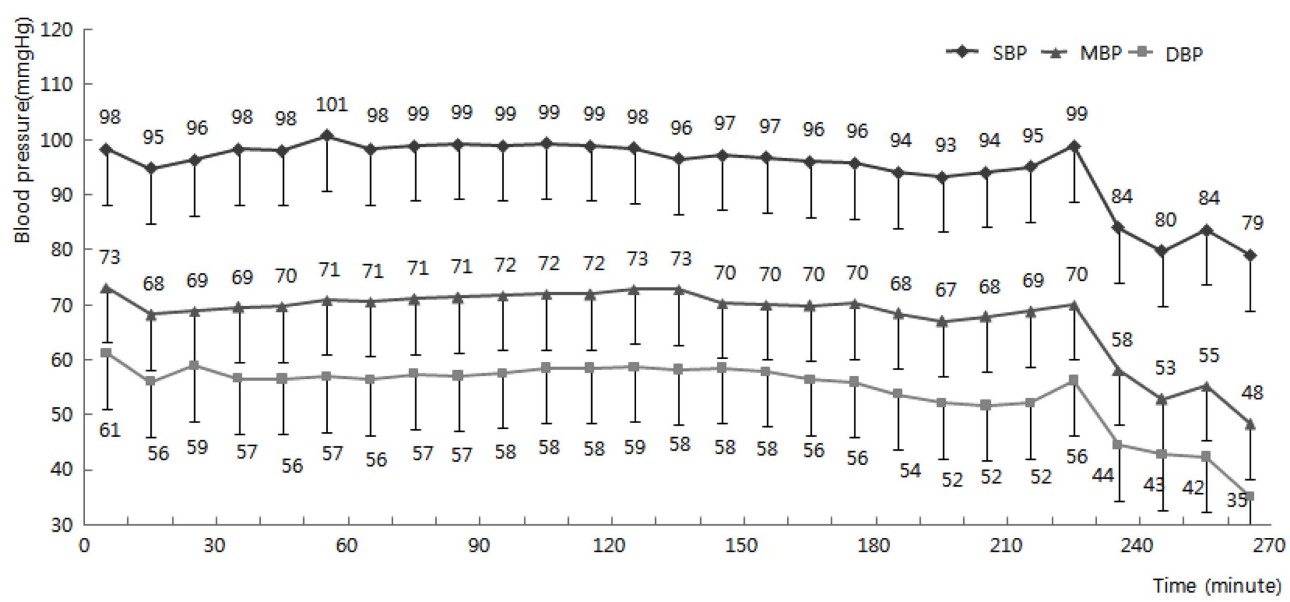

Fig 2. Systolic, mean and diastolic blood pressures of horses during anesthesia. 
Table 4. Logistic regression to find out influencing factors on mortality during and/or after anesthesia $(n=508)$

\begin{tabular}{cccccc}
\hline \hline Variables & Coefficient & SE & OR & $\mathrm{Z}$ & $\mathrm{P}>|\mathrm{z}|$ \\
\hline $\begin{array}{c}\text { Anesthetic } \\
\text { duration }\end{array}$ & -0.006 & 0.006 & 0.994 & -1.08 & 0.278 \\
$\begin{array}{c}\text { Anesthetic agent } \\
\text { concentration }\end{array}$ & 0.795 & 0.653 & 2.215 & 1.22 & 0.224 \\
Mean MBP & -0.032 & 0.034 & 0.968 & -0.97 & 0.334 \\
Mean HR & 0.043 & 0.035 & 1.044 & 1.24 & 0.215 \\
$\begin{array}{c}\text { Colic surgery } \\
\text { Upper airway } \\
\text { surgery }\end{array}$ & $3.658^{*}$ & 0.762 & 38.802 & 4.8 & $0.000^{*}$ \\
\hline
\end{tabular}

HR: heart rate, MBP: mean blood pressure, OR: odds ratio, SE: standard error, ${ }^{*} p<0.05$

tality rates compared to horses that received musculoskeletal system surgery (Table 4).

Among 20 horses, 16 horses were euthanized and 4 horses died during and/or after anesthesia. All horses (13) that were euthanized during general anesthesia were considered to have a poor to grave prognosis for survival. Causes for euthanasia of horses during and/or after recovery were laminitis (1), myopathy (1), and refracture (1). Among 4 died horses, 3 horses developed upper airway obstruction while they were in recovery, and 1 horse had recurrent signs of abdominal pain and died (Table 5).

In colic cases, significant risk factors such as elevated HR, $\mathrm{RR}$, abnormal mucus membrane color and gastric reflux were recorded under preanesthetic comments. The causes of death included endotoxemia due to intestine rupture prior to surgery, and severe volvulus and torsion that was not able to be corrected surgically. Perioperative fatalities were high at $16.4 \%$ in colic surgery, followed by $0.7 \%$ in orthopedic surgery, and $6.6 \%$ in airway surgery.

\section{Discussion}

Epidemiological studies of anesthetic and surgical mortality are effective methods of studying incidents in anesthesia during surgery, and alteration needed in anesthetic and surgical practice to reduce perioperative complications $(6,8,9)$. Con-

Table 5. Detail information of horses died or euthanized during and/or after general anesthesia

\begin{tabular}{|c|c|c|c|c|c|c|c|c|c|}
\hline & $\mathrm{B}$ & A & S & W & Operation & Cause of death & $\mathrm{T}$ & $\mathrm{O}$ & Comments \\
\hline 1 & TB & 3 & $\mathrm{~F}$ & 456 & Colic & Intestine rupture & DA & $\mathrm{E}$ & MM: pale pink \\
\hline 2 & TB & 6 & M & 450 & Colic & Intestine rupture & DA & $\mathrm{E}$ & $\begin{array}{c}\text { MM: pale pink, } \\
\text { HR: } 72 / \text { min, RR: } 64 / \text { min }\end{array}$ \\
\hline 3 & $\mathrm{~TB}$ & 3 & G & 426 & Colic & Intestine rupture & DA & $\mathrm{E}$ & \\
\hline 4 & TB & 5 & $\mathrm{~F}$ & 465 & Colic & Intestine rupture & DA & $\mathrm{E}$ & \\
\hline 5 & NTB & & M & 606 & Colic & Intestine rupture & DA & $\mathrm{E}$ & HR: $120 / \mathrm{min}$, irregular respiration \\
\hline 6 & NTB & 11 & M & 565 & Colic & Intestine rupture & DA & $\mathrm{E}$ & Eye reflex remained \\
\hline 7 & NTB & 9 & M & 581 & Colic & $\begin{array}{l}\text { Small intestine } \\
\text { strangulation }\end{array}$ & DA & $\mathrm{E}$ & MM: blue, CRT 3 4 sec \\
\hline 8 & TB & 2 & M & 510 & Colic & Intestine rupture & DA & $\mathrm{E}$ & $\begin{array}{l}\text { MM: dark red, hypotension gastric } \\
\text { reflux thorough nasal cavity }\end{array}$ \\
\hline 9 & NTB & 11 & G & 570 & Colic & $\begin{array}{l}\text { Cecum, large colon } \\
\text { displacement }\end{array}$ & DA & $\mathrm{E}$ & MM: pale pink, hypotension \\
\hline 10 & NTB & 13 & $\mathrm{~F}$ & 538 & Colic & $\begin{array}{l}\text { Ileocecal } \\
\text { intussusception }\end{array}$ & DA & $\mathrm{E}$ & \\
\hline 11 & TB & 4 & M & 525 & Cpx chip $f x$ & Laminitis of $\mathrm{BF}$ & $\mathrm{AR}$ & $\mathrm{E}$ & \\
\hline 12 & TB & 3 & M & 454 & Colic & Intestine rupture & DA & $\mathrm{E}$ & tachycardia \\
\hline 13 & Foal & 2 & M & 260 & Colic & Inoperable problem & DA & $\mathrm{E}$ & $\mathrm{EtCO}_{2}: 70 \mathrm{mmHg}$ \\
\hline 14 & NTB & 9 & $\mathrm{G}$ & 540 & DDSP & Airway obstruction & DR & $\mathrm{N}$ & \\
\hline 15 & $\mathrm{~TB}$ & 3 & $\mathrm{~F}$ & 515 & RC3 slab fx & Myopathy & $\mathrm{AR}$ & $\mathrm{E}$ & \\
\hline 16 & TB & 4 & $\mathrm{~F}$ & 473 & DDSP & Airway obstruction & DR & $\mathrm{N}$ & \\
\hline 17 & TB & 4 & $\mathrm{~F}$ & 467 & LMT3 Fx & Refracture & DR & $\mathrm{E}$ & \\
\hline 18 & $\mathrm{~TB}$ & 2 & $\mathrm{~F}$ & 450 & Colic & Inoperable problem & DA & $\mathrm{E}$ & \\
\hline 19 & TB & 3 & G & 491 & $\mathrm{LH}$ & Airway obstruction & DR & $\mathrm{N}$ & BUN: $10.5 \mathrm{mg} / \mathrm{dl}$ \\
\hline 20 & TB & 2 & $\mathrm{~F}$ & 440 & Colic & Colic recurrence & $\mathrm{AR}$ & $\mathrm{N}$ & \\
\hline
\end{tabular}

A: age, AR: after recovery, B: breed, BF: both forelimbs, BUN: blood urea nitrogen, cpx: carpal bone, CRT: capillary refill time, DA: during anesthesia, DDSP: dorsal displacement of the soft palate, DR: during recovery, E: euthanasia, F: female, fx: fracture, G: gelding, HR: heart rate, LH: laryngeal hemiplegia, LMT3: left third metatarsal bone, M: male, MM: mucus membrane, N: natural death, NTB: non-thoroughbred, O: outcome, RC3: radial carpal bone, RR: respiratory rate, S: sex, T: time of death, TB: thoroughbred, W: weight. 
fidential enquiry of perioperative equine fatalities (CEPEF) has already provided a lot of information suggesting how clinical practice might be changed to improve the anesthetic and surgical managements of equine patients (6).

Several studies about perioperative fatalities were conducted recently. In most studies, mortality rates were calculated separately in case of colic and non-colic surgery because the low survival rate on colic surgery might have occurred by their primary disease $(1,5,8)$. In this study, the fatality rate in colic cases was higher $(16.4 \%, n=14 / 85)$ compared to noncolic cases $(1.2 \%, n=6 / 500)$. Logistic regression used to find out influencing factors on fatality showed a significant estimated odds ratio (OR) for colic surgery (CI: 3.658, OR: 38.82 ) and respiratory surgery (CI: 2.781, OR: 16.136).

This result of colic surgery might be caused by death and/ or euthanasia including endotoxemia due to intestine rupture before surgery and severe volvulus and torsion that could not be corrected surgically. Although horses with colic that developed hypotension or $\mathrm{PaO}_{2}<10.6 \mathrm{kPa}$ during anesthesia had an increased fatality rate in the previous study (14), there was no significant effect of blood pressure on perioperative fatality in this study.

In case of upper airway surgery, airway obstruction was the main cause of death during and after recovery. Nasal cavity edema is the most common cause of post-operative respiratory obstruction (4). Three horses died due to airway obstruction in the recovery room after airway surgery including tieforward or tie-back techniques. Therefore, maintaining a patent airway and supplying sufficient oxygen are crucial steps during recovery from anesthesia. Keeping the oro-tracheal tube in the airway until full recovery is recommended. In addition, it was reported that the incidence of postoperative complication was greater in draft horses than thoroughbreds in laryngoplasty cases (12), but this comparison could not be carried out due to insufficient number of airway surgery in draft horses of this study.

Complications such as fractures account for $23-26 \%$ of mortality rate associated with inhalant anesthesia, and myopathy or neurological complications represent $7 \%$ of mortality causes $(7,8)$. In this study, one horse out of 20 horses showed refracture as a post-operative complication. It is worth noting that post-operative fractures represented nearly $1 / 4$ of all deaths and that these fractures were not restricted to horses undergoing fracture repair (8). Therefore, surgeons always need to be mindful of the possibility of post-operative fracture in the recovery room regardless of the types of surgery.

Although the MBP was maintained within normal ranges above $60 \mathrm{mmHg}$ during anesthesia, one horse experienced myopathy in the recovery room after orthopedic surgery in this study. Myopathy can be a serious or fatal complication of equine anesthesia. Its incidence and severity can be reduced by maintaining muscle perfusion through a combination of careful positioning which reduces the intra-compartmental pressure and allows free venous drainage, by avoiding prolonged hypotension (17). Hypotension and duration of anesthesia play an important role in the development of postoperative myopathy and neuropathy in draft horses with acute abdominal disease (13). Dobutamine, a synthetic positive inotrope, has been widely used to treat the anesthetic-induced hypotension in conjunction with intravenous fluid therapy and minimizing the delivered concentration of volatile agent (3). Therefore, proper use of ionotropes with fluid to maintain blood pressure and to prevent myopathy is recommended too.

To minimize recovery complications from anesthesia, 1) proper positioning and providing adequate padding of the patient intra-operatively, 2) maintaining MBP above $70 \mathrm{mmHg}$ during anesthesia, 3) providing adequate analgesia for safe recovery, 4) ensuring patency of airway after extubation, and 5) insufflating $\mathrm{O}_{2}$ at a flow rate of $15 \mathrm{~L} / \mathrm{min}$ are generally recommended in routine clinics (4). Improved recovery from anesthesia is associated with shorter, less invasive surgical procedures and slower recovery (18). Consequently, anesthetic management of horses undergoing surgery can be improved greatly, particularly when BP is monitored, hypotension is treated, post-anesthetic myopathy is prevented and ventilation is controlled (16).

In conclusion, careful analysis of anesthetic and surgical results and assessment of the influencing factors on mortality would help reducing the fatality in equine clinics. It is recommended to prepare and perform perioperative intensive care for colic surgery and close monitoring for upper airway surgery during recovery. For further progress, it is also important to complete the anesthetic record for all patients that receive general anesthesia and surgery.

\section{Acknowledgements}

All data of this study were used under permission of KRA equine hospital.

\section{References}

1. Bidwell LA, Bramlage LR, Rood WA. Equine perioperative fatalities associated with general anesthesia at a private practice-a retrospective case series. Vet Anaesth Analg 2007; 34: 23-30.

2. Clarke KW, Hall LW. A survey of anesthesia in small animal practice. J Vet Anaesth 1990; 17: 4-10.

3. De Vries A, Brearley JC, Taylor PM. Effects of dobutamine on cardiac index and arterial blood pressure in isofluraneanaesthetized horses under clinical conditions. J Vet Pharmacol Ther 2009; 32: 353-358.

4. Flaherty D, Nolan A, Reid J. Complications during recovery from anaesthesia in equine patient. Equine Vet Edu 2005; 15: 53-59.

5. Hall LW. Disturbances of cardiopulmonary function in anaesthetized horses. Equine Vet J 1971; 3: 95-98.

6. Johnston GM. Findings from the CEPEF epidemiological studies into equine perioperative complications. Equine Vet Edu 2005; 15: 64-68.

7. Johnston GM, Eastment JK, Taylor PM, Wood JLN. Is isoflurane safer than halothane in equine anesthesia? Results 
from a prospective multicentre randomized controlled trial. Equine Vet J 2004; 36: 64-71.

8. Johnston GM, Eastment, JK, Wood, JLN, Taylor PM. The confidential enquiry into perioperative equine fatalities (CEPEF): mortality results of Phases 1 and 2. Vet Anaesth Analg 2002; 29: 159-170.

9. Johnston GM, Taylor PM, Holmes MA, Wood JLN. Confidential enquiry of perioperative equine fatalities (CEPEFI): preliminary results. Equine Vet J 1995; 27: 193-200.

10. Jones RS. Editorial II: Comparative mortality in anesthesia. Br J Anaesth 2001; 87: 813-815.

11. Mee AM, Cripps RS, Jones RS. A retrospective study of mortality associated with general anesthesia in horses: Emergency procedures. Vet Rec 1998; 142: 307-309.

12. Olson KN. Anesthesia for laryngoplasty with or without sacculectomy in 85 draft horses: comparison with 322 Thoroughbreds. Vet Anaesth Analg 2002; 29: 97-112.

13. Rothenbuhler R, Hawkins JF, Adams SB, Lescun TB, Weil AB, Glickman LT, Fessler JF, Glickman NG. Evaluation of surgical treatment for signs of acute abdominal pain in draft horses: 72 cases (1983-2002). J Am Vet Med Assoc 2006; 228: $1546-1550$.

14. Trim CM, Adams JG, Cowgill LM, Ward SL. A retrospective survey of anesthesia in horses with colic. Equine Vet J 1989; 21: 84-90.

15. Voulgaris DA, Hofmeister EH. Multivariate analysis of factors associated with post-anesthetic times to standing in isofluraneanesthetized horses: 381 cases. Vet Anaesth Analg 2009; 36: 414-420.

16. Wagner AE, Mama KR, Steffey EP, Hellyer PW. A comparison of equine recovery characteristics after isoflurane or isoflurane followed by a xylazine-ketamine infusion. Vet Anaesth Analg 2008; 35: 154-160.

17. Young SS. Post-anaesthetic myopathy. Equine Vet Edu 1993; 5: 200-203.

18. Young SS, Taylor PM. Factors influencing the outcome of equine anesthesia: a review of 1,314 cases. Equine Vet $\mathrm{J}$ 1993; 25: 147-151.

\title{
한국마사회에서 실시한 말의 전신마취에 대한 후향 분석 \\ 김아람*** • 양영진** - 송대영** • 김진갑** - 김하기** · 권철재** - 서유진** · 정효훈** • 이인형*1 \\ *서울대학교 수의과대학, **한국마사회 동물병원
}

\begin{abstract}
요 약 : 본 연구는 한국마사회 동물병원에서 시행한 전신마취 결과를 분석하고 마취 중·후에 발생한 사망률에 영향 을 미치는 인자를 찾기 위하여 실시되었다. 총 585 두의 환마에서 전신마취가 실시되었으며, 수술의 빈도는 정형외과 수 술(410)이 가장 많이 실시되었고, 산통 수술(85), 호흡기 수술(45) 순이었다. 585 두 중 20 두가 마취 중 - 후에 죽거나 안락사 되었다. 20 두 중 14 두는 산통 수술을 받았고, 3 두는 정형외과 수술, 3 두는 호흡기 수술을 받았다. 세부 사망원 인으로는 산통 수술에서는 장파열, 호흡기 수술에서는 기도폐색이었다. 정형외과 수술에서는 근육병증, 재골절, 제엽염 이 안락사의 원인이었다. 결과적으로 산통 수술과 호흡기 수술 후의 사망률은 정형외과 수술 후보다 높게 나타났다 $(p<0.01)$. 이상의 결과로부터, 산통수술을 받는 말의 사망률이 가장 높은 것을 확인하였으며, 그 원인은 예후불량에 의한 안락사이었다. 말의 마취 전후 사망률을 낮추기 위하여, 산통 수술을 받는 말은 수술 전후의 집중 관리가 필요하 고, 호흡기 수술을 받는 말은 회복 중 주의 깊은 관찰이 추천된다.
\end{abstract}

주요어 : 전신, 흡입, 마취, 사망률, 말 